\title{
Targeted deletion of mouse Rad1 leads to deficient cellular DNA damage responses
}

\author{
Chunbo Zhang ${ }^{1,2,4^{*}}$, Yuheng Liu ${ }^{1,3^{*}}$, Zhishang $\mathrm{Hu}^{1}$, Lili $\mathrm{An}^{1}$, Yikun $\mathrm{He}^{2}$, Haiying Hang ${ }^{1 凶}$ \\ ${ }^{1}$ National Laboratory of Biomacromolecules, and the Center for Computational and Systems Biology, Institute of Biophysics, \\ Chinese Academy of Sciences, Beijing 100101, China \\ ${ }^{2}$ College of Life Science, Capital Normal University, Beijing 100037, China \\ ${ }^{3}$ Graduate School of the Chinese Academy of Sciences, Beijing 100049, China \\ ${ }^{4}$ Current address: School of Pharmacy, Faculty of Medicine, The Chinese University of Hong Kong, Shatin, Hong Kong, China \\ \ Correspondence: hh91@sun5.ibp.ac.cn \\ Received April 23, 2011 Accepted May 5, 2011
}

\section{ABSTRACT}

The Rad1 gene is evolutionarily conserved from yeast to human. The fission yeast Schizosaccharomyces pombe Rad1 ortholog promotes cell survival against DNA damage and is required for $G_{2} / M$ checkpoint activation. In this study, mouse embryonic stem (ES) cells with a targeted deletion of Mrad1, the mouse ortholog of this gene, were created to evaluate its function in mammalian cells. Mrad1 ${ }^{-1-}$ ES cells were highly sensitive to ultraviolet-light (UV light), hydroxyurea (HU) and gamma rays, and were defective in $G_{2} / M$ as well as $S / M$ checkpoints. These data indicate that Mrad1 is required for repairing DNA lesions induced by UV-light, HU and gamma rays, and for mediating $\mathrm{G}_{2} / \mathrm{M}$ and $\mathrm{S} / \mathrm{M}$ checkpoint controls. We further demonstrated that Mrad1 plays an important role in homologous recombination repair (HRR) in ES cells, but a minor HRR role in differentiated mouse cells.

KEYWORDS Rad1, DNA damage, checkpoint signaling, DNA repair, homologous recombination repair

\section{INTRODUCTION}

Cells face endogenous and exogenous assaults that damage genomic DNA. But eukaryotic cells have conserved surveillance mechanisms, which could detect the DNA lesions and send the signals to the DNA repair system and the cell cycle control machinery, to coordinate DNA repair and minimize negative effects of these lesions. The cell cycle delay induced via the checkpoint mechanism is thought to provide extra time for DNA damage repair, and to prevent cell cycle progression into critical phases that could lead to lethality (Hartwell and Weinert, 1989; Paulovich and Hartwell, 1995; Zhou et al., 2010).

Rad9, Rad1 and Hus1 are a group of genes conserved from yeast to human that play key roles in the cell cycle signaling networks. Their protein products form a ring-shaped heterotrimer, named the 9-1-1 complex (Doré et al., 2009; Sohn and Cho, 2009; Xu et al., 2009). It is believed that this complex is important for the functions of DNA repair as well as the activation of cell cycle checkpoints (Shiomi et al., 2002; Bermudez et al., 2003; Ellison and Stillman, 2003). Interestingly, human Rad1 (i.e., RAD1) also exists as monomer besides forming the 9-1-1 complex in cells, and the function of this form of the protein is unknown (Burtelow et al., 2001). In fission yeast Schizosaccharomyces pombe, disruption mutants of the three genes resulted in similar phenotypes, including viability, sensitivity to UV-light, the replication inhibitor hydroxyurea $(\mathrm{HU})$, as well as gamma rays, and defective $S / M$ and $G_{2} / M$ checkpoint control (al-Khodairy and Carr, 1992; Enoch et al., 1992; Lieberman et al., 1992; Murray et al., 1991; Rowley et al., 1992). Disruption of the budding yeast Saccharomyces cerevisiae counterparts, Mec3 (schus1), Rad17 (scrad1) and Ddc1 (scrad9), also caused similar phenotypes in the corresponding mutants, including hypersensitivity to $U V$ light, $H U$ and gamma rays, and $G_{2} / M$ checkpoint defect, but not a disruption of the S/M checkpoint defect (Longhese et al., 1997; Lydall and Weinert, 1997). Mouse cells with a disruption of Mrad9 or Mhus1, the mouse homologues of rad 9 or hus 1 , were successfully created, and also exhibited significantly higher sensitivity to UV light, HU and gamma rays than the wild-type cells (Weiss et al., 2000;

\footnotetext{
"These authors contributed equally to the work.
} 
Hopkins et al., 2004). The cell cycle checkpoint functions of Mrad9 and Mhus1 were reported to be different but the comparison was based on the data using two different cell types (Weiss et al., 2000; Hopkins et al., 2004; Wang et al., 2004). The Mhus $1^{-1-}$ cells are mouse embryonic fibroblasts (MEF), while the $\mathrm{Mrad}^{-/-}$cells are mouse embryonic stem cells (ES). Mhus $1^{1--}$ MEFs were defective in the UV lightinduced intra-S phase checkpoint, but functioned normally with respect to the $G_{2} / M$ checkpoint (Weiss et al., 2003). In contrast, $\mathrm{Mrad}^{-1-}$ ES cells were not markedly defective in the UV light-induced intra-S phase checkpoint, but failed to maintain $G_{2} / M$ checkpoint control following the exposure to gamma rays (Weiss et al., 2000; Hopkins et al., 2004).

Results from human RAD1 knockdown using siRNA suggested that the gene is an important element for cell growth and is required for the recovery of DNA synthesis following HU treatment (Bao et al., 2004). The same study showed that reduced RAD1 protein level caused a defect in the intra-S phase checkpoint but did not affect the $G_{2} / M$ checkpoint. However, rad1-disrupted yeast cells failed to arrest in response to ionizing radiation exposure (al-Khodairy and Carr, 1992; Enoch et al., 1992; Rowley et al., 1992; Lydall and Weinert, 1997).

Although targeted deletion of Mrad9 and Mhus1 in mouse cells and mice have been reported (Weiss et al., 2000; Hopkins et al., 2004; Levitt et al., 2005; Levitt et al., 2007; Hu et al., 2008; Yazinski et al., 2009; An et al., 2010), equivalent studies for Mrad1 have not been published. Such investigation is important to reveal the gene functions that are not detectable when RAD1 protein is only partially expressed in siRNA knockdown cells (Bao et al., 2004) or heterozygous cells (Han et al., 2010). In the present study, we constructed mouse ES cells with a targeted deletion of Mrad1 gene and investigated Mrad1 function in these cells. Our results showed that Mrad1 homozygously deleted ES cells were viable, but were defective in $\mathrm{G}_{2} / \mathrm{M}$ checkpoint maintenance as well as the HU-induced S/M checkpoint, and were highly sensitive to UV light, HU and gamma rays. Interestingly, the differentiation of $\mathrm{Mrad1}^{-/-}$ES cells modulated the capability of double-strand breaks (DSB) repair.

\section{RESULTS}

\section{Construction of mouse ES cells with homozygous disruptions of Mrad1}

$\mathrm{Mrad1}^{+/-}$ES cells were obtained as previously described (Han et al., 2010). The neo gene product can destroy antibiotic G418, and the Mrad1 ${ }^{+/-}$ES cells contained one allele of disrupted genomic Mrad1 bearing a copy of neo gene. We hypothesize that increasing G418 concentration in the medium might force the amplification of the copy number of neo and even replace the remaining wild type genomic Mrad1 with the neo-bearing disrupted genomic Mrad1. To obtain $\mathrm{Mrad1}^{-/-}$clones, the Mrad1 ${ }^{+/-}$ES cells were incubated with $3.2-4.4 \mathrm{mg} / \mathrm{mL}$ G418 instead of the original $300 \mu \mathrm{g} / \mathrm{mL}$ G418 for 20 days, and from 96 survivors, six colonies bearing Mrad1 homozygous deletion were identified by Southern blotting (Fig. 1A). These results were confirmed using Northern blotting (Fig. 1B) and RT-PCR (Fig. 1C).
A

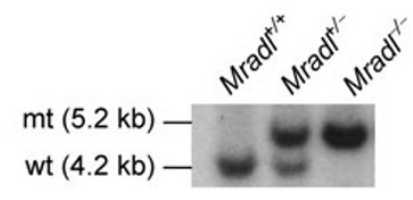

C

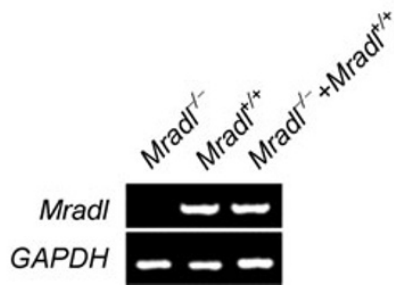

B

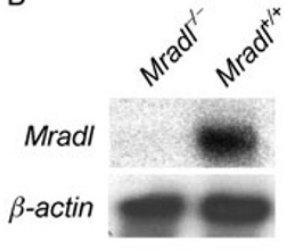

Figure 1. Targeted deletion of mouse Mrad1. (A) Southern blot of Mrad1 in mouse ES cells. Genomic DNA from wild-type and targeted ES clones were digested with HindIII and hybridized with probes corresponding to flanking sequences. Bands indicate wild-type and deleted Mrad1 alleles. (B) Northern blot of Mrad1 RNA in mouse ES cells. The $\beta$-actin gene was used as a control to demonstrate equivalent sample loading. The probe for Mrad1 RNA was made from the digested sequence of genomic Mrad1 gene. (C) RT-PCR to assess Mrad1 RNA levels. Total RNA was isolated from $\mathrm{Mrad1}^{+/+}$and Mrad1 $^{-1-}$ ES cells, the latter ectopically expressing Mrad1. Gapdh RNA levels were used as an internal control. Primer pairs and other experimental details are described in MATERIALS AND METHODS.

\section{Mrad1 deletion retards cell proliferation and alters cell cycle phase distribution}

RAD1 knockdown by siRNA reduced the proliferation rate of human cells (Bao et al., 2004). Consistent with this result, $\mathrm{Mrad1}^{-/-}$ES cells grew significantly slower than the wild type control population (Fig. 2A), and formed much smaller colonies (Fig. 2B). We examined the cell cycle phase distributions of $\mathrm{Mrad1}^{-/-}$and $\mathrm{Mrad1}^{+/+}$cells with flow cytometry, and found that significantly more $\mathrm{Mrad}^{-1-}$ cells accumulated in the $G_{2} / M$ phase than the wild-type cells (Fig. 2C), suggesting the mutant cells proceeded through $\mathrm{G}_{2} / \mathrm{M}$ at a significantly slower pace. Bromodeoxyuridine (BrdU) incorporation analysis showed that $S$ phase progression rate was reduced by homozygous deletion of Mrad1 (Fig. 2D). All the aforementioned changes in the cell cycle caused by Mrad1 deletion were reversed by ectopically expressing 
A

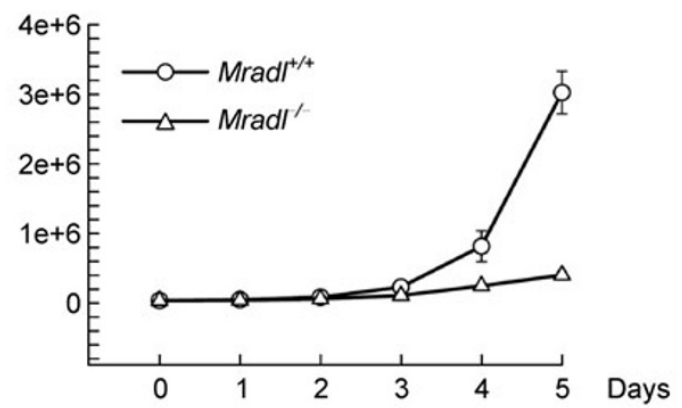

B

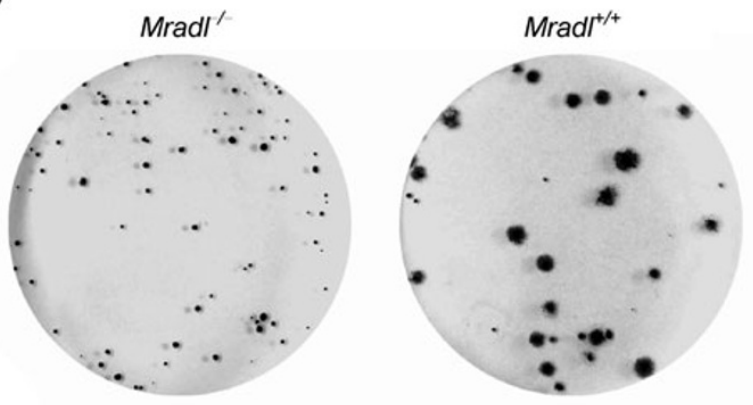

C

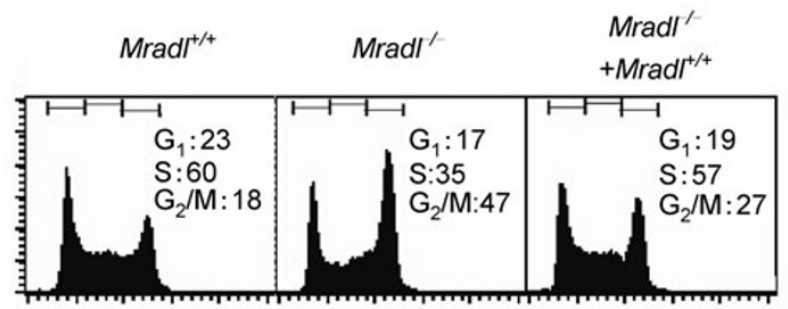

D

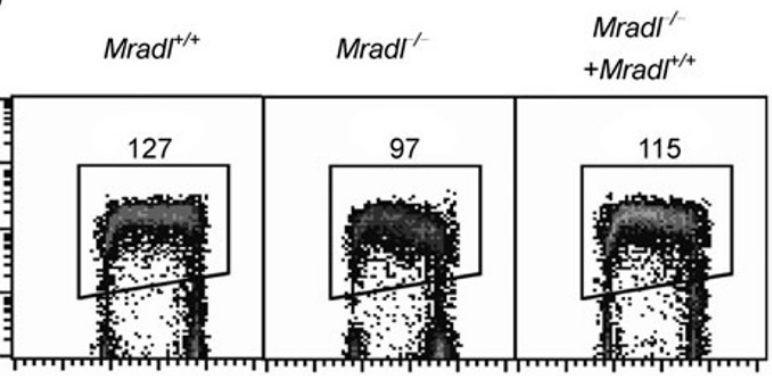

Figure 2. Deletion of Mrad1 in mouse ES cells retards cell proliferation and changes cell cycle phase distribution. (A) Proliferation of $\mathrm{Mrad1}^{+/+}$and $\mathrm{Mrad1}^{-1-} \mathrm{ES}$. The average results were derived from three independent experiments. (B) Cells were grown on Petri dishes at $37^{\circ} \mathrm{C}$ with $5 \% \mathrm{CO}_{2}$ for 10 days and then stained to visualize colony formation. Mrad1 ${ }^{-1-}$ ES cells (left) formed much smaller colonies than Mrad1 ${ }^{+/+}$ES cells (right). (C) Asynchronously dividing ES cells were fixed and stained with PI. Cell cycle distribution was analyzed by flow cytometry. Deletion of Mrad1 resulted in an aberrant accumulation of cells in the $G_{2} / M$ phase, suggesting a slower progression through this phase of cell cycle. The percentage of each cell population in $G_{1}, S$ and $G_{2} / M$ phases is shown in the graphs as indicated. (D) S-phase DNA replication was assayed by simultaneous measurement of DNA content and BrdU incorporation. Deletion of Mrad1 resulted in a slowdown of S phase DNA synthesis. The number inside each graph is the geometric mean of BrdU incorporation per $10 \mathrm{~min}$. All the above experiments had been repeated at least three times. Only one set of representative data was presented here. 
A

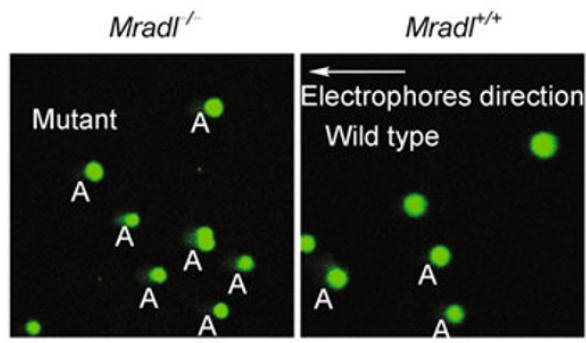

C

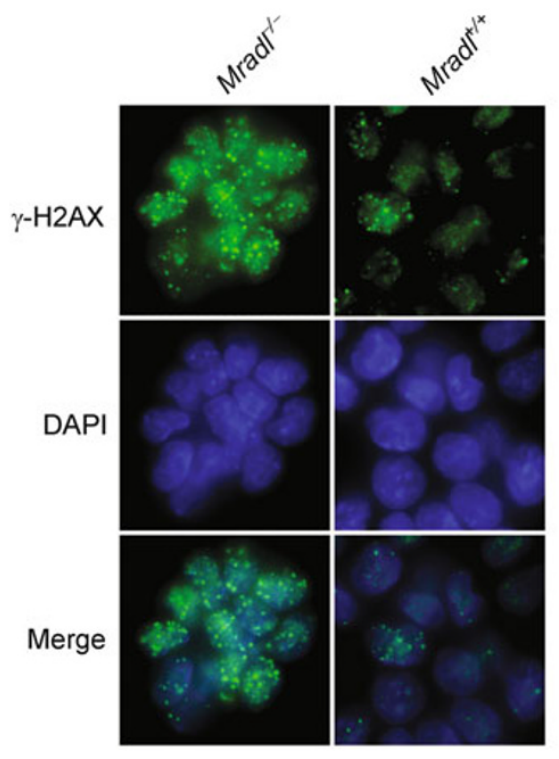

B

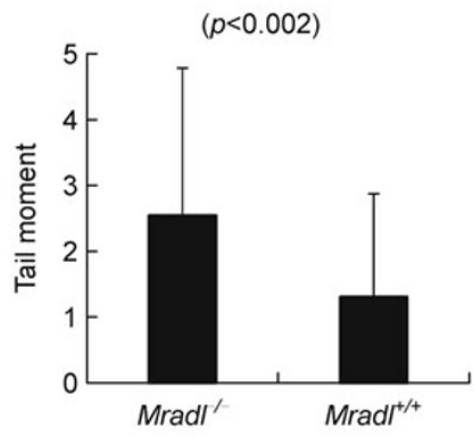

D

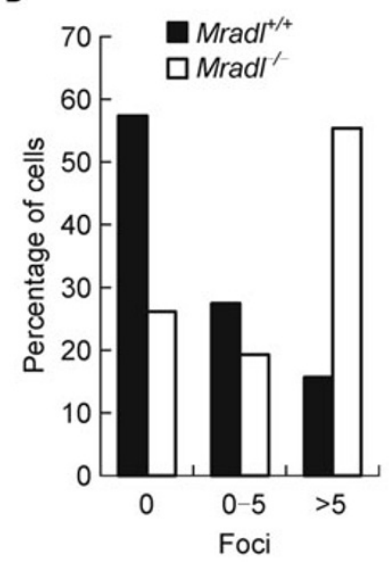

$E$

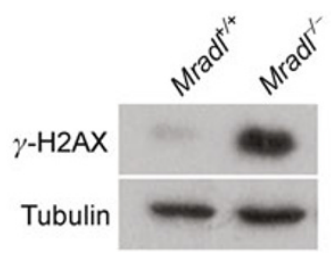

Figure 3. Deletion of Mrad1 leads to increased frequency of DNA lesions. (A) Mrad1 $1^{-/-}$and $M r a d 1^{+/+}$ES cells were analyzed for DNA lesions using a Comet Assay kit as described in MATERIALS AND METHODS. (B) The tail moment of Mrad1 ${ }^{-1-}$ ES cells was measured and the mean $\pm S D$ is depicted. The tail moment of the mutant cells was significantly larger than wild-type control $(p<0.002)$. (C) Spontaneous DNA double-strand breaks were detected by $\mathrm{y}-\mathrm{H} 2 \mathrm{AX}$ labeling. (D) Quantitative assessments were made by counting foci in at least 100 cells of each phenotype, and the percentage of foci containing cells is shown. (E) Whole cell lysates from $\mathrm{Mrad}^{+/+}$and $\mathrm{Mrad1}^{-/-}$ES cells were subjected to western blotting using anti-y-H2AX antibody, with tubulin served as a loading control.

Mrad1 (Fig. 2C and 2D; data not shown), and thus these alterations were due to the lack of Mrad1 function.

The increased accumulation of $\mathrm{Mrad}^{1 /-}$ cells in the $\mathrm{G}_{2} / \mathrm{M}$ phase might result from activation of the $G_{2} / M$ checkpoint by DNA lesions, and therefore, we monitored the DNA breaks in wild type and $\mathrm{Mrad1}^{-1-}$ ES cells using an alkaline comet assay for all types of DNA lesions and a histone $\mathrm{y}-\mathrm{H} 2 \mathrm{AX}$ assay for DSBs. The comet tail moment in $\mathrm{Mrad1}^{-1-}$ ES cells was significantly higher than that in $\mathrm{Mrad1}^{+/+}$cells (Fig. $3 \mathrm{~A}$ and $3 \mathrm{~B}$ ), indicating the presence of more DNA lesions in the mutant. These results were confirmed by the histone $y-\mathrm{H} 2 \mathrm{AX}$ assay, in which more foci (Fig. 3C and 3D) as well as a higher level of histone $\mathrm{Y}-\mathrm{H} 2 \mathrm{AX}$ were detected in the mutant population (Fig. 3E), reflecting enhanced DNA DSBs in Mrad1 $^{-1-}$ ES cells.

\section{Failure of $\mathrm{Mrad1}^{-1-}$ ES cells to maintain ionizing radiation-induced $\mathrm{G}_{2} / \mathrm{M}$ checkpoint control}

DNA damage-induced arrest in $G_{2}$ phase is one of the most prominent cell cycle checkpoints in eukaryotic cells. Fission yeast $S$. pombe rad1 is required for this cell cycle arrest in 
response to ionizing radiation exposure (Freire et al., 1998; Udell et al., 1998). Therefore, we examined whether the role of Mrad1 in the $\mathrm{G}_{2} / \mathrm{M}$ checkpoint is evolutionarily conserved. $\mathrm{Mrad1}^{+/+}$and $\mathrm{Mrad1}^{-1-}$ cells, as well as the Mrad1 ${ }^{-/-}$cells ectopically expressing Mrad1 were irradiated with $10 \mathrm{~Gy}$ of gamma rays, harvested at 4, 6, 8, 10 and $12 \mathrm{~h}$ after exposure, and then processed for flow cytometric analysis to assess cell cycle phase distribution. Only data from untreated, 6 and $10 \mathrm{~h}$ time points are presented here because the rest of data essentially indicated the same trends. The percentage of cell populations in each phase of the cell cycle is shown in graphic (Fig. 4) and tabular formats (Table 1). Subpopulations of both $\mathrm{Mrad}^{1^{+/+}}$and $\mathrm{Mrad1}^{-/-}$ES cells increased in the $\mathrm{G}_{2} / \mathrm{M}$ phase and decreased in the $G_{1}$ and $S$ phases post irradiation. This pattern, lacking $G_{1}$ arrest but exhibiting radiation-inducible $G_{2}$ arrest, is a typical response of wild-type ES cells to gamma rays (Aladjem et al., 1998). This result indicated that Mrad1 is not indispensable to activate the $G_{2} / M$ checkpoint. However, in contrast to the wild-type cells, Mrad1-deficient cells accumulated in the $G_{1}$ phase (arrows in Fig. 4). To assess whether the small $G_{1}$ subpopulation of cells came from the $\mathrm{G}_{2} / \mathrm{M}$ phase post irradiation, colcemid, which disrupts the mitotic spindle and traps cells in mitosis, was added to the cells. The results showed that incubation of the cells with colcemid eliminated the small $G_{1}$ subpopulation accumulation, and therefore the cells progressed from the $G_{2} / M$ phase (Fig. 4), suggesting the important role of Mrad1 in maintaining the DNA damage-induced $\mathrm{G}_{2} / \mathrm{M}$ checkpoint control. This conclusion was confirmed by the fact that the $G_{2} / M$ checkpoint defect was rescued by the ectopic expression of Mrad1.

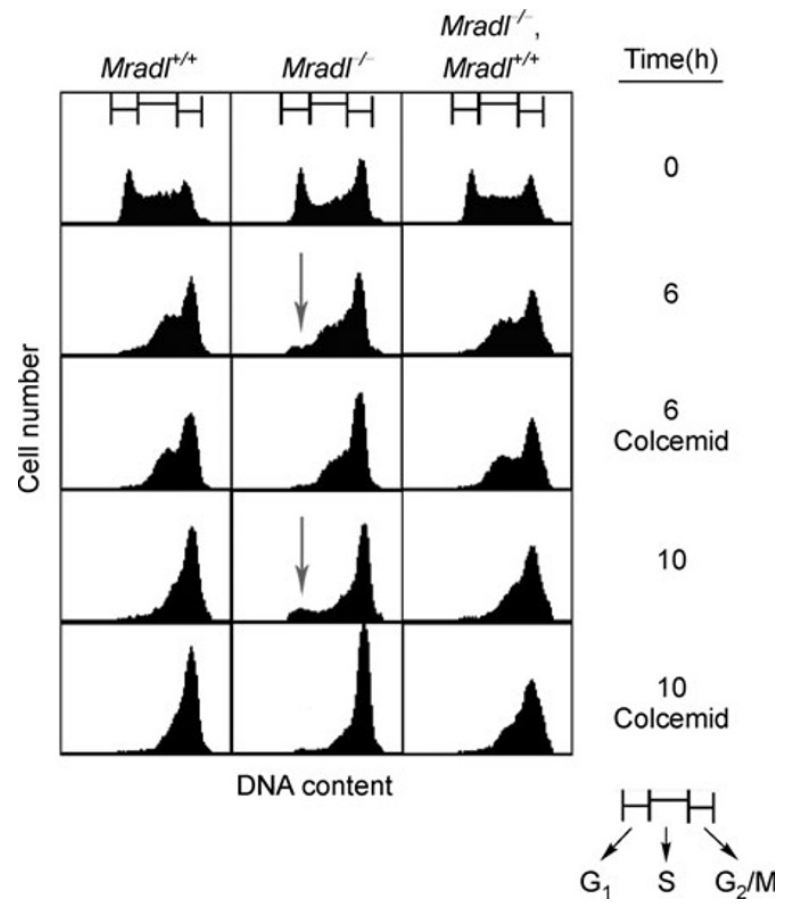

Figure 4. Mrad1 deletion leads to a deficiency in $\mathbf{G}_{2}$ arrest induced by ionizing radiation exposure. $\mathrm{Mrad}^{+/+}$, $\mathrm{Mrad1}^{-/-}$ES cells, and Mrad1 ${ }^{-/-}$ES cells ectopically expressing Mrad1 were mock-treated or treated with $10 \mathrm{~Gy}$ of gamma rays in the absence or presence of colcemid, and then analyzed by flow cytometry. $G_{1}, S$ and $G_{2} / M$ regions of the profiles are delineated on top of graph for the calculations of cell distribution in each phase as indicated in Table 1.

Table 1 Percentage of cells in different phases of the cell cycle at indicated times post-irradiation with 10 Gy of gamma rays

\begin{tabular}{|c|c|c|c|c|}
\hline \multirow[t]{2}{*}{ Genotype } & \multirow[t]{2}{*}{ Post-irradiation time (h) } & \multicolumn{3}{|c|}{ Percentage of population in all cycle phase (\%) } \\
\hline & & $\mathrm{G}_{1}$ & $\mathrm{~S}$ & $\mathrm{G}_{2} / \mathrm{M}$ \\
\hline \multirow{5}{*}{$\mathrm{Mrad}^{+/+}$} & 0 & 22.27 & 48.43 & 24.55 \\
\hline & 6 & 1.56 & 45.14 & 52.95 \\
\hline & $6+$ colcemid & 0.64 & 43.18 & 56.05 \\
\hline & 10 & 0.79 & 27.01 & 71.04 \\
\hline & $10+$ colcemid & 0.38 & 23.01 & 76.26 \\
\hline \multirow{5}{*}{ Mrad1 $^{-/-}$} & 0 & 24.07 & 35.41 & 40.51 \\
\hline & 6 & 5.73 & 42.85 & 51.18 \\
\hline & $6+$ colcemid & 1.22 & 37.50 & 61.11 \\
\hline & 10 & 9.02 & 24.90 & 65.29 \\
\hline & $10+$ colcemid & 0.73 & 14.56 & 83.70 \\
\hline \multirow{5}{*}{$\operatorname{Mrad1}_{1}{ }^{/-}+\operatorname{Mrad}^{+/+}$} & 0 & 23.58 & 44.94 & 31.36 \\
\hline & 6 & 1.15 & 46.86 & 50.40 \\
\hline & $6+$ colcemid & 0.59 & 42.90 & 55.25 \\
\hline & 10 & 1.13 & 32.94 & 63.04 \\
\hline & $10+$ colcemid & 0.44 & 30.35 & 66.40 \\
\hline
\end{tabular}




\section{Mrad1 disruption in ES cells alters S/M checkpoint control}

S. pombe rad1 is required to block cells with incomplete DNA replication from moving into the $\mathrm{M}$ phase of cell cycle (S/M checkpoint), while the $S$. cerevisiae ortholog, Rad17 (scRad1), is dispensable for the checkpoint. To determine whether the S/M checkpoint in mouse ES cells is Mrad1dependent, we examined the level of phospho-histone-H3 ( $\mathrm{\gamma}$ H3) throughout the cell cycle. Histone-H3 is specifically phosphorylated during mitosis. After treatment with $\mathrm{HU}$ for different times, ES cells were labeled with anti- $y-\mathrm{H} 3$ antibody, stained with propidium iodide (PI) for DNA content, and then analyzed by flow cytometry. Incubation with $\mathrm{HU}$ reduced the number of $\mathrm{y}-\mathrm{H} 3$ positive $\mathrm{Mrad} 1^{+/+}$cells with $2 \mathrm{~N}$ DNA content because most cells were blocked in $S$ phase and thus fewer moved into the $\mathrm{M}$ phase. Few $\mathrm{Mrad}^{+/+}$cells with less than $2 \mathrm{~N}$ DNA content were $\mathrm{Y}-\mathrm{H} 3$ positive after $\mathrm{HU}$ treatment, indicating that the wild type cells have a normal S/M checkpoint (Fig. 5 and Table 2). In contrast, the number of $\mathrm{Y}-\mathrm{H} 3$ positive $\mathrm{Mrad1}^{-/-}$cells with less than 2N DNA content dramatically

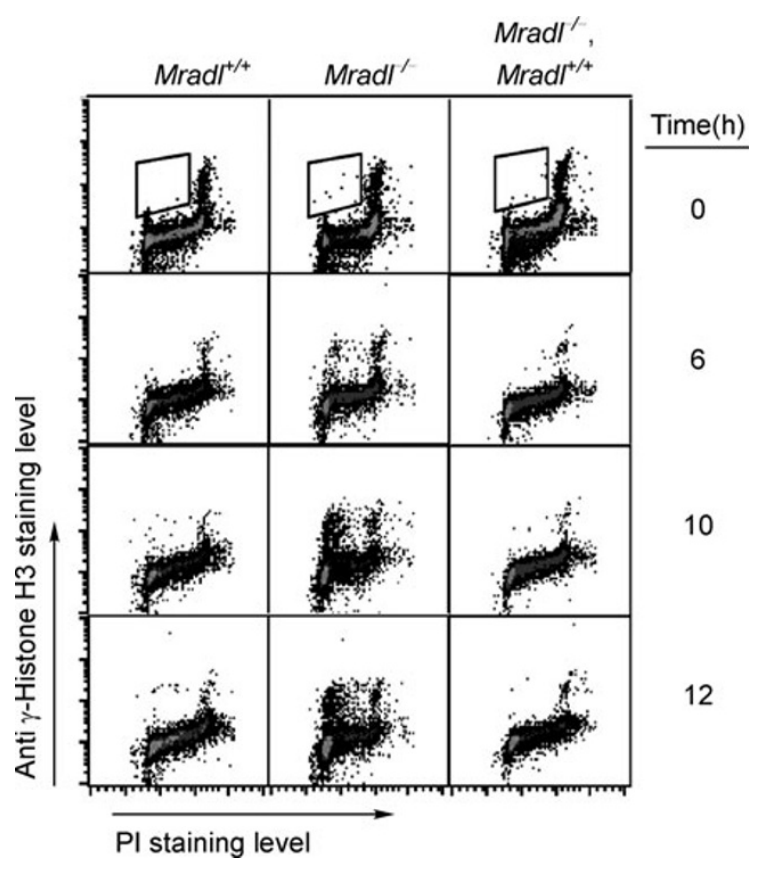

Figure 5. Mrad1 deletion leads to an S/M checkpoint control defect. Mrad1 ${ }^{+/+}, \mathrm{Mrad1}^{-/-}$ES cells, and Mrad1 ${ }^{-1-}$ ES cells ectopically expressing Mrad1 were treated or mocktreated with $1 \mathrm{mmol} / \mathrm{L} \mathrm{HU}$ for various times. Cells were collected and labeled with antibodies against the mitotic marker phosphor-histone $\mathrm{H} 3$, stained with $\mathrm{PI}$, and analyzed by flow cytometry. Staining intensity for PI ( $x$-axis) is plotted versus staining intensity of phosphor-histone $\mathrm{H} 3$ ( $y$-axis). Cells in the boxed region correspond to the prematurely condensed chromosome mitotic fraction. The percentage of boxed cells in the graphs is listed in Table 2.
Table 2 Percentage of cells with premature condensed chromosomes (phosphor-histone $\mathrm{H} 3$ labeled cells with less than 2N DNA) treated for indicated times with $1 \mathrm{mmol} / \mathrm{L} \mathrm{HU}$

\begin{tabular}{lcc}
\hline Genotype & $\begin{array}{c}\text { Treatment } \\
\text { time }(\mathrm{h})\end{array}$ & $\begin{array}{c}\text { Percentage of } \mathrm{y}-\mathrm{H} 3 \text { positive } \\
\text { with less }\end{array}$ \\
\hline & 0 & 0.03 \\
Mrad1 $^{+/+}$ & 6 & 0.04 \\
& 10 & 0.12 \\
& 12 & 0.24 \\
& 0 & 0.07 \\
Mrad1 $^{-/-}$ & 6 & 0.83 \\
& 10 & 4.88 \\
& 12 & 6.04 \\
Mrad1 $^{-/-}+$Mrad1 $^{+/+}$ & 0 & 0.01 \\
& 6 & 0.02 \\
& 10 & 0.04 \\
\hline
\end{tabular}

increased after HU treatment. Mrad1-deficient ES cells ectopically expressing Mrad1 showed the same pattern as wild-type cells. Therefore, Mrad1 is essential for the S/M checkpoint control.

\section{Mrad1 is not essential for the intra-S phase checkpoint induced by UV light}

The intra-S phase cell cycle checkpoint monitors DNA replication and delays DNA synthesis in the presence of DNA damage. We demonstrated that Mrad1-null cells are highly sensitive to UV light (see below). Therefore, we determined whether the UV-induced intra-S phase checkpoint of the mutant cells was aberrant. $\mathrm{Mrad1}^{+/+}$and $\mathrm{Mrad1}^{-/-}$cells were treated with UV light, and then pulse-labeled with $10 \mu \mathrm{mol} / \mathrm{L}$ BrdU at designated times post treatment to detect DNA replication by flow cytometry. The incorporation rates of BrdU into DNA in both cell populations dramatically reduced at 40,90 and $180 \mathrm{~min}$ after irradiation, and the kinetics were similar (Fig. 6). Thus, these findings indicate that deletion of Mrad1 does not affect the intra-S phase checkpoint control after exposure to UV light.

\section{Mrad1-deleted ES cells are hypersensitive to UV light, $\mathrm{HU}$ and gamma rays}

Previous research showed that Rad1 associates with Hus1 and Rad9 in a 9-1-1 heterotrimer to respond to DNA damage (Hang and Lieberman, 2000; Rauen et al., 2000; LindseyBoltz et al., 2001; Roos-Mattjus et al., 2002; Parrilla-Castellar et al., 2004). Both Mhus $1^{-/-}$MEF cells and Mrad $^{-/-}$mouse ES cells are highly sensitive to genotoxins, including UV light, HU and gamma rays (Weiss et al., 2000; Hopkins et al., 2004; Wang et al., 2004; Wang et al., 2006). S. pombe rad1::ura $4^{+}$ 


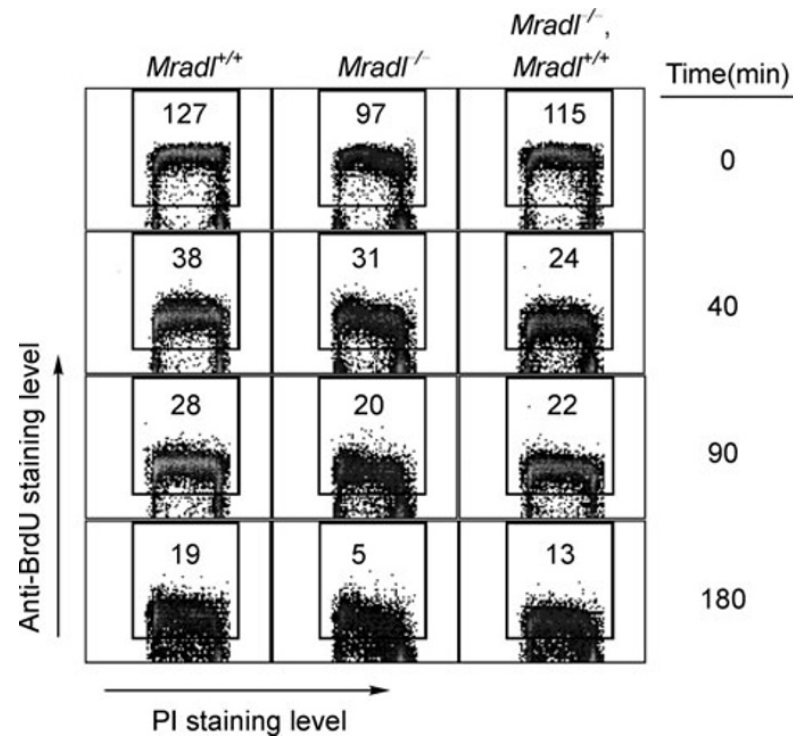

Figure 6. Mrad1-deficient ES cells demonstrate a normal delay in DNA synthesis in response to UV light exposure. $\mathrm{Mrad1}^{1^{+/+}}, \mathrm{Mrad1}^{-/-}$ES cells, and Mrad1 ${ }^{-/-}$ES cells ectopically expressing Mrad1 were treated or mock-treated with $20 \mathrm{~J} / \mathrm{m}^{2}$ UV, labeled with BrdU at the indicated times post exposure, stained with FITC-conjugated anti-BrdU antibody and PI, and then analyzed by flow cytometry. Staining intensity for $\mathrm{PI}(x$ axis) versus staining intensity for $\mathrm{BrdU}$ ( $y$-axis) is indicated. Geometric means of the FITC fluorescence in BrdU-positive cells, which reflects the BrdU uptake rate by the $S$ phase subpopulation of cells, are shown in each sample.

cells are also extremely sensitive to these DNA damaging agents (Freire et al., 1998; Udell et al., 1998). Therefore, we examined whether Rad1 in mouse ES cells plays an important role in promoting resistance to these genotoxins. As shown in Fig. 7, Mrad1 $1^{-1-}$ ES cells were extremely sensitive to UV light, HU and gamma rays compared to the wild type control population. To confirm the sensitivities are due to a defect in Mrad1, resistance was examined in the mutant cells ectopically expressing the wild-type gene. As indicated in Fig. 7, expression of wild-type Mrad1 compensated the resistance to UV light, HU and gamma rays in $\mathrm{Mrad1}^{-1-}$ ES cells, thus indicating that Mrad1 gene mediates the resistance to these agents.

\section{Deletion of Mrad1 does not affect expression of other cell cycle checkpoint genes}

p21, p53, Hus1 and Rad9 are important cell cycle checkpoint genes, and the expression levels of $p 21, p 53$, Hus1 and Rad9 were examined by northern blotting to gain a mechanistic insight into the potential influence of Mrad1 deletion on the regulation of these genes. The results indicated that homozygous deletion of Mrad1 did not affect expression of these cell cycle checkpoint genes (Fig. 8). Mrad1 ${ }^{-1-}$ cells bearing
A

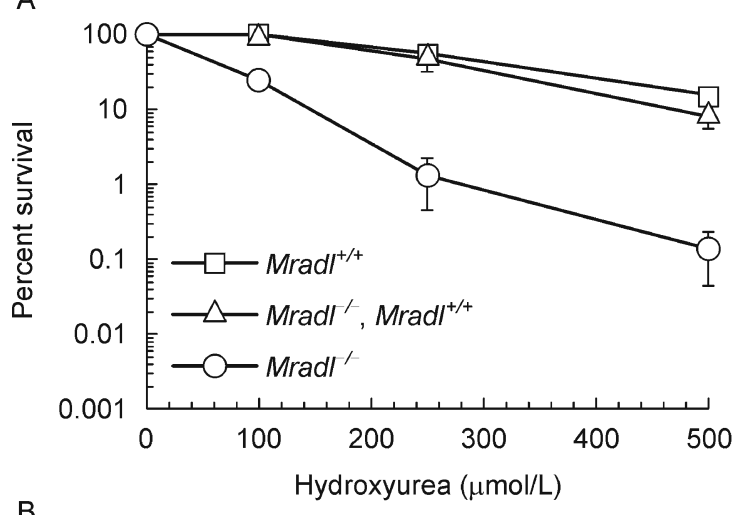

B

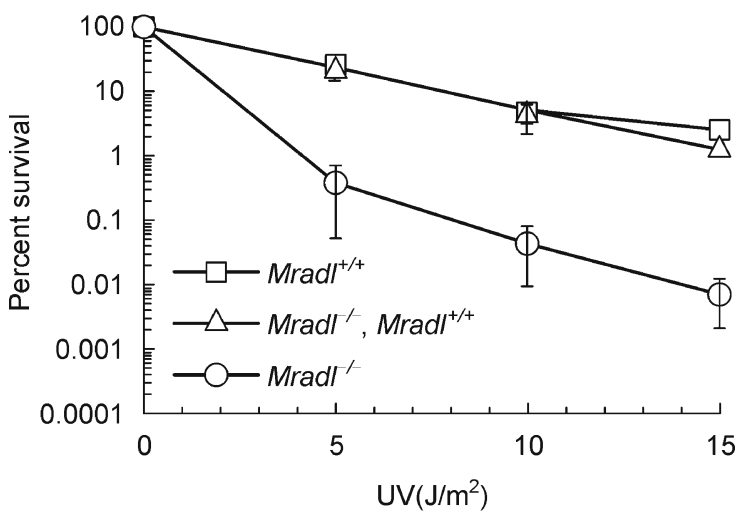

C

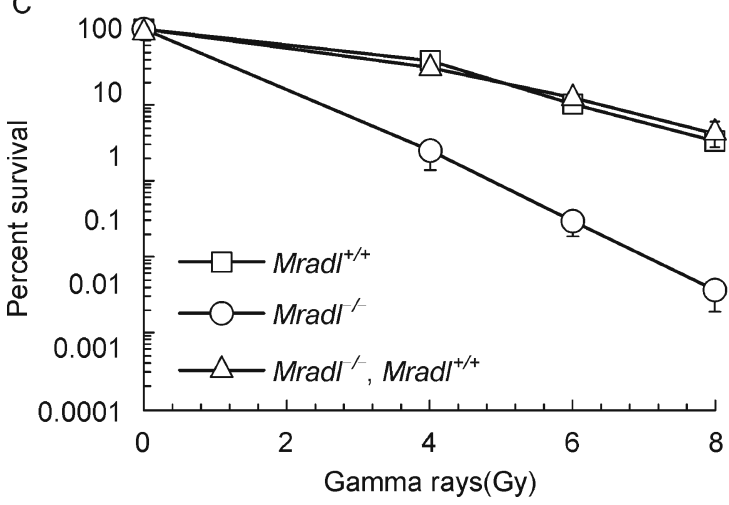

Figure 7. Mrad1-deficient cells have increased sensitivity to DNA-damaging agents. Mrad1 $1^{+/+}, \mathrm{Mrad1}^{-/-} \mathrm{ES}$ cells, and $\mathrm{Mrad1}^{-1-}$ ES cells ectopically expressing Mrad1 were treated as described in MATERIALS AND METHODS, and colony formation was used to assess their sensitivity to hydroxyurea (A), UV (B), and gamma rays (C). Points in all the graphs represented the average of three independent experiments, with bars indicating standard deviation.

the Mrad1 cDNA also displayed similar expression levels of these cell cycle checkpoint RNAs, except for the increased expression of Mhus1, and the deletion of Mrad1 did not affect Mhus1 RNA level. Therefore, Mrad1 deletion did not cause a dramatic shift in RNA levels corresponding to this group of cell cycle checkpoint genes, suggesting that the deletion caused 
A

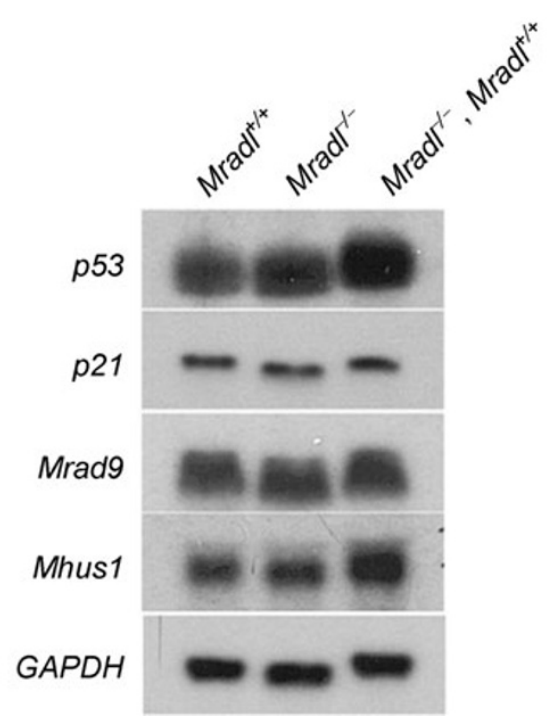

B

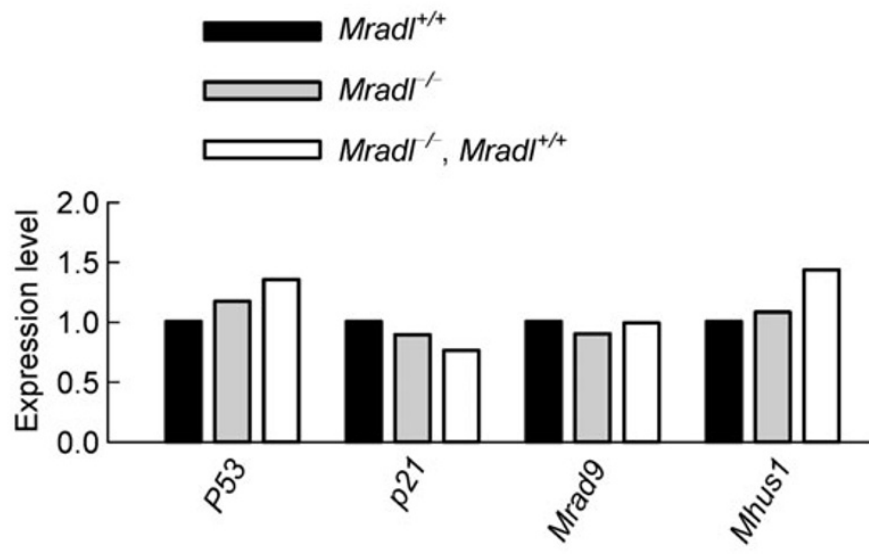

Figure 8. Northern blotting analyses of cell cycle checkpoint genes in mouse ES cells. (A) Total RNA prepared from $\mathrm{Mrad1}^{+/+}, \mathrm{Mrad1}^{-/-}$ES cells, and Mrad1 ${ }^{-/-}$ES cells ectopically expressing Mrad1 was subjected to Northern blotting hybridization with indicated ${ }^{32} \mathrm{P}$-labeled cDNA probes. Gapdh served as a loading control. (B) Quantitative analysis of RNA levels corresponding to the checkpoint control genes. The ratio of radioactive intensity of indicated gene over Gapdh levels in (A) was quantified with AlphaEaseFC ${ }^{\mathrm{TM}}$ software (Alphalmager 2200, Alpha Innotech Corp., San Leandro, CA).

defects of cell checkpoints and altered cell cycle distribution not through regulating the expression of $p 21, p 53$, Hus 1 or Rad9.

\section{Differentiated Mrad1-deleted ES cells have more efficient HR repair}

It has been reported that ES cells have more efficient DNA repair than differentiated ES cells in response to various DNA-damage agents (Maynard et al., 2008; Tichy and Stambrook, 2008). However, in the cell survival assay, we found that $\mathrm{Mrad1}^{-/-}$ES cells were hypersensitive to IR, but retinoic acid (RA)-induced differentiated $\mathrm{Mrad1}^{-1-}$ ES cells had nearly identical sensitivity as the wild type cells (Fig. 9A). Meanwhile, undifferentiated and differentiated $\mathrm{Mrad}^{+/+}$ES cells displayed similar resistance to the same doses of irradiation (Fig. 9B). Leukemia inhibitory factor (LIF) is routinely added to ES cell medium to prevent ES cells from differentiation. Here we obtained similar results when $\mathrm{Mrad1}^{-1-}$ ES cells were cultured in RA-containing medium as well as LIF-free medium (Fig. 9C), confirming that mouse ES cell differentiation compensated for DNA repair defects caused by Mrad 1 deletion. Treatment by gamma rays causes DSBs, which are repaired by two major pathways, nonhomologous end joining (NHEJ) and homologous recombination (HR). Using an established in vivo HR assay (Pierce et al., 2001), we found that the loss of Mrad1 caused significant reduction in HR repair capacity, but differentiation could largely compensate it in Mrad1 ${ }^{-/-}$ES cells (Fig. 9D and 9E).

\section{DISCUSSION}

In fission yeast $S$. pombe, rad1 is a key component that mediates multiple cellular responses to DNA damage, including a role in cell cycle checkpoint (Murray et al., 1991; al-Khodairy and Carr, 1992; Enoch et al., 1992; Lieberman et al., 1992; Rowley et al., 1992; Parker et al., 1998). However, the function of this gene in mammals is not clear. In this report, we examined the activities of Mrad1, the mouse ortholog of S. pombeRad1, by creating and characterizing the mouse ES cells with deletion of Mrad1. We demonstrated that Mrad1-deficient ES cells were highly sensitive to UV light, $\mathrm{HU}$ and gamma rays (Fig. 7 ), defective in $S / M$ and $G_{2} / M$ cell cycle checkpoint controls (Fig. 4-6), and prone to accumulate DNA lesions under normal growth conditions (Fig. 3). These data indicate that Mrad1 plays essential roles in the resistance to

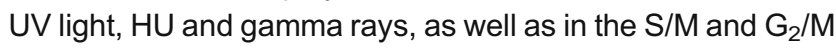
checkpoints.

As shown by previous reports (Burtelow et al., 2001; RoosMattjus et al., 2002), as well as 9-1-1 complex crystal structure (Doré et al., 2009; Sohn and Cho, 2009; Xu et al., 2009), Rad1 along with Rad9 and Hus1 in a trimeric checkpoint complex were believed to have similar functions. Indeed as we showed above, many phenotypes such as the hypersensitivity to HU, UV light and gamma rays are similar among Mrad1-deletion, Mrad9-deletion and Mhus1-deletion mouse cells (Fig. 7) (Weiss et al., 2000, 2003; Hopkins et al., 2004). In addition, mouse ES cells with Mrad1-deletion and Mrad9-deletion are similarly deficient in $\mathrm{G}_{2} / \mathrm{M}$ and $\mathrm{S} / \mathrm{M}$ 
A

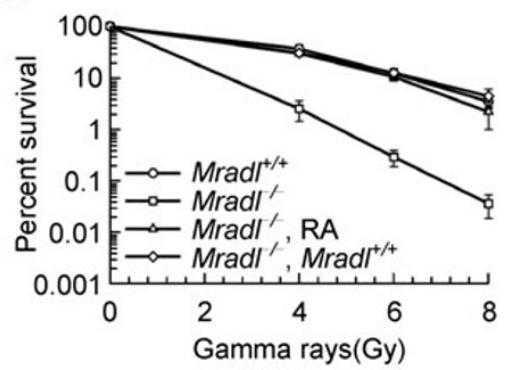

B

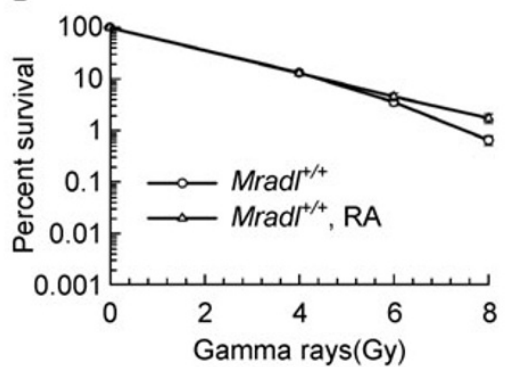

C

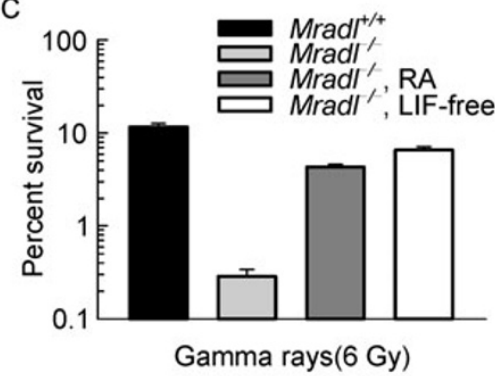

D
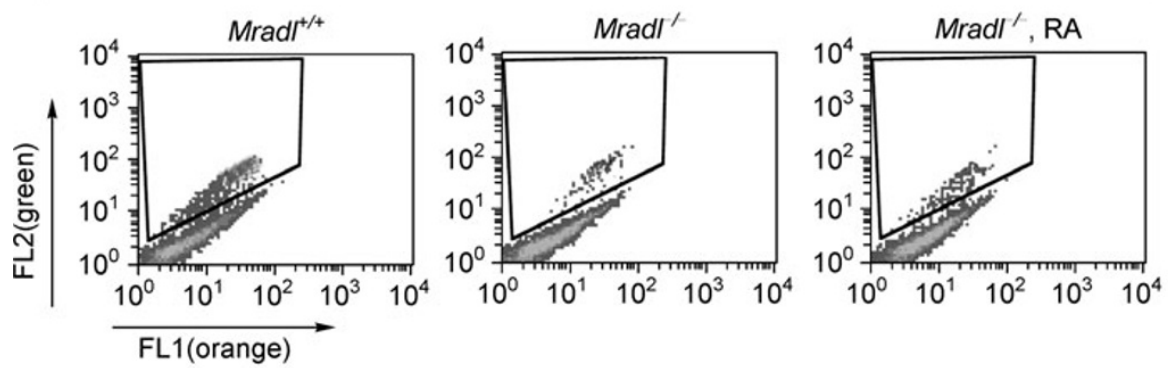

E

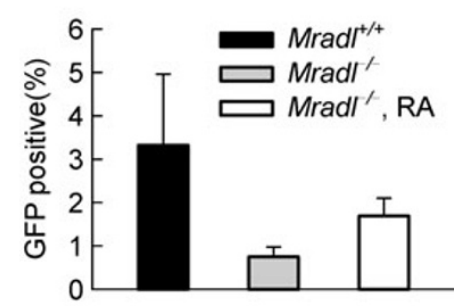

Figure 9. Differentiated Mrad1 $^{-1-}$ ES cells have increased DSBs repair capability. After treating with gamma rays, enhanced resistance was observed in differentiated $\mathrm{Mrad1}^{-1-}$ ES cells (A), but not $\mathrm{Mrad1}^{+/+}$ES cells (B). Other differentiation-inducing method indicated the same results $(C)$. Points in all the graphs represented the average of three independent experiments with bars indicating standard deviation. Meanwhile, flow cytometric analysis demonstrated attenuated HR in Mrad1 $1^{-/-}$ES cells, but partial compensation in differentiated $\mathrm{Mrad1}^{-1-}$ ES cells. ES cells containing a chromosomal DR-GFP reporter were cotransfected with the expression vectors for the I-Scel endonuclease. In vivo cleavage of DR-GFP reporter at the I-Scel site of SceGFP gene and repair by the downstream iGFP repeat directed HR resulted in GFP-positive cells (D). Summary of the percentage of HR deficient cells from each cell lines is presented. Bars represent the average of three independently isolated hprtDRGFP subclones for each cell line (E). Error bars are \pm S.D. $(n=3)$.

checkpoint maintenance, but intact in intra-S phase checkpoint, which is in contrast to Mhus1 embryonic fibroblasts (EF) (Weiss et al., 2000, 2003; Hopkins et al., 2004). Taken together, Rad1, Rad9 and Hus1 are likely to work in the 9-1-1 complex for the resistance to $\mathrm{HU}, \mathrm{UV}$ light and gamma rays as well as for the maintenance of $S / M$ and $G_{2} / M$ checkpoints in mouse ES cells. The phenotype differences in intra-S phase, $\mathrm{S} / \mathrm{M}$ and $\mathrm{G}_{2} / \mathrm{M}$ checkpoints between Mrad1 or Mrad9-deleted mouse ES cells and Mhus1-deleted mouse EF cells are probably due to the various differentiation states, suggesting the different functions of these genes in cell cycle checkpoints in ES and EF cells.

Consistent with the above hypothesis, we found in this study that the differentiated $\mathrm{Mrad1}^{-/-}$cells induced by RA and LIF-free media had similar resistance to gamma rays as undifferentiated or differentiated $\mathrm{Mrad1}^{+/+}$cells (Fig. 9). Interestingly, the resistance to $\mathrm{HU}$ or UV light was similar between undifferentiated and differentiated $\mathrm{Mrad}^{1-1-}$ cells (our unpublished data). These results together suggest that differentiation has various influence on different DNA repair pathways. It is still unknown whether differentiation of $\mathrm{Mrad}^{-/-}$cells can also enhance their resistance to gamma rays. This experiment is critical to clarify whether the differentiation-associated resistance change is 9-1-1 complex dependent or only Rad1-dependent. Indeed, there are significant amounts of individual Rad1 molecules in human cells (Burtelow et al., 2001; our unpublished data).

ES cells were reported to have higher DNA repair abilities than differentiated cells (Maynard et al., 2008; Tichy and Stambrook, 2008). Our results are inconsistent with these reports. It is possible that repair factors work differently at various stages of differentiation, and the comparison between ES and differentiated cells only at certain stages probably does not reflect all the DNA repair situations of mammalian cells during differentiation. In addition, various DNA repair pathways are probably differently influenced by cell differentiation as shown in this study while only the resistance to gamma rays, but not to HU or UV light, was altered by the differentiation of mouse ES cells. As already shown by many studies, differentiation is largely regulated and reflected by chromatin status and many chromatin remodeling factors play important roles in DNA repair pathways. DNA repair at different stages of differentiation attracts more researches and will generate further insights into DNA repair mechanisms.

HR repair was a major component that was altered in DSB 
repair from mouse ES $\mathrm{Mrad1}^{-1-}$ cells to RA-induced differentiated mouse $\mathrm{Mrad1}^{-/-}$cells (Fig. 9D and 9E), but it only accounted for half of the altered DSB. It is likely that NHEJ also changed during the differentiation. If this is true, the differentiation would modulate the common part(s) of both repair pathways, and the chromatin status during DSB repairing process might be modulated

A study of human HCT116 cells with RAD1 siRNA demonstrated no effect of the corresponding reduced protein levels on the $G_{2} / M$ checkpoint, but impaired intra-S phase checkpoint control was observed (Bao et al., 2004). Our study using Mrad1-deficient ES cells revealed the opposite results: a defective $G_{2} / M$ and an intact intra-S phase checkpoint (Fig. 4 and 6). The difference in cell types might contribute to the different checkpoint responses. As for the lack of a role of human $R A D 1$ in $\mathrm{G}_{2} / \mathrm{M}$ checkpoint as shown by knockdown strategy, a possibility also exists that a low level of RAD1 is sufficient to support $G_{2} / M$ checkpoint function.

\section{MATERIALS AND METHODS}

\section{Growth of ES cells, gene targeting, and generation of Mrad1-deficient cells}

$\mathrm{Mrad1}^{+/-}$ES cells were prepared as previously described (Han et al., 2010). To generate $\mathrm{Mrad1}^{-/-} \mathrm{ES}$ cells, $\mathrm{Mrad1}^{1^{+-}}$ES cells were grown in a medium containing $3.2-4.4 \mathrm{mg} / \mathrm{mL}$ G418. For the construction of $\mathrm{Mrad1}^{-1-}$ ES cells that ectopically express wild-type gene, the cells were transfected with pZeoSV2-Mrad1, grown in the presence of zeocin $(30 \mu \mathrm{g} / \mathrm{mL})$, and resistant clones were examined by RT-PCR to identify Mrad1 transcription.

The Mrad1 expression vector was made by PCR from mouse cDNA with the primers: 5'-ATTCGGCCGACTCGAGTCAAGACTCAGGAACTTCTTCATCAG-3' and 5'-GTCCATAAGCTTGCCGCCACCATGCCTCTCCTAACCCAGTACAATG-3'. The product was cut with Xhol/Hindlll and subcloned into pZeoSV2 (Invitrogen).

Retinoic acid (RA)-induced differentiated ES cells were prepared using normal $\mathrm{Mrad1}^{+/+}$and $\mathrm{Mrad1}^{-/-}$ES cells cultured in $8 \mu \mathrm{mol} / \mathrm{L}$ RA for 5 days.

\section{Southern blotting and PCR assays to assess genotypes}

Genomic DNA was isolated from ES cells and mouse tails using published methods (Weiss et al., 2000). For southern blotting, DNA was digested with HindIII, separated on a $0.7 \%$ agarose gel, then transferred to a nylon membrane, and hybridized to a ${ }^{32} \mathrm{P}$ labeled probe, which was generated by PCR using primers: $5^{\prime}-$ GTGGCCTAGGTGGTTGCGTATCTGAAC-3' and 5'-GTCGGCTCCGAGAAGAAGGATGCTCC-3' with mouse genomic DNA as template.

To genotype ES cells and mice by PCR, the reaction was performed using genomic DNA templates and the following primer pairs: 5'-GTCTCAGGTTTTCACACATCTTCC-3' and 5'-GCTTATATTCTAGAAACCTTCCTGTATG-3'. After denaturation at $94^{\circ} \mathrm{C}$ for $5 \mathrm{~min}, 35$ cycles of amplification $\left(94^{\circ} \mathrm{C}\right.$ for $13 \mathrm{~s}, 59^{\circ} \mathrm{C}$ for $30 \mathrm{~s}$, at $72^{\circ} \mathrm{C}$ for $3 \mathrm{~min} 10 \mathrm{~s}$ ) were followed, with a final extension at $72^{\circ} \mathrm{C}$ for $10 \mathrm{~min}$.

\section{Northern blotting and RT-PCR}

Total RNA was isolated from ES cells using RNeasy Mini kit (QIAGEN) as described by the manufacturer. For Northern blotting, $10 \mu \mathrm{g}$ RNA was fractionated in a $1.2 \%(w / v)$ formaldehyde-agarose gel and then transferred to a Hybond-N membrane. Templates for probes were made by PCR using the following primers: Mhus1, 5'ATGAAGTTTCGCGCCAAGAT-3' and 5'-AGTCTGGGATGGAGGGTTCT-3'; Mrad9, 5'-ACTATTGAGGATTCCTTGCTGGATG3' and 5'-ACAGTGAACGAAACTTCTTGGGTG-3'; Mrad1, 5'GGAGTTTCCTGCATTTCCAAAAG-3' and 5'-GTCCATAAGCTTCCTCTCCTAACCCAGTACAATGAAGAG-3'; neo, 5'-CTACGCGTCGACATTGAACAAGATGGATTGCACGC-3' and 5'-AGGAATTCAGACATGATAAGATACATTGATGAG-3'; p21, 5'-ATGTCCAATCCTGGTGATGTCCG-3' and 5'-CAGGCTGGTCTGCCTCCGTTTTC$3^{\prime}$. Then, the membrane was hybridized with the probes, which were made using [ $\alpha-32 P]-d C T P$ and the Prime-a-gene labeling system (Amersham). The labeled membrane was washed and used to expose X-ray film.

For RT-PCR, $2 \mu \mathrm{g}$ total RNA was reverse-transcribed to cDNA using the SuperScript First-Strand Synthesis System for RT-PCR (Invitrogen). PCR amplification was carried out using the following primer pairs: Mrad1 ORF, 5'-TCCATAAGCTTCCTCTCCTAACCCAGTACAATGAAGAG-3' and 5'-ACTGCCATAACTCGAGTCAAGACTCAGGAACTTCTTCATCAGG-3'; Mrad1 upstream, 5'-ATGCCTCTCCTAACCCAGTACAATG-3' and 5'-TTCTTCCTGAATGACAAATTCCTG-3'; Gapdh, 5'- GCAAAGTGGAGATTGTTGCC-3' and 5'-CCGTATTCATTGTCATACCA-3'.

\section{Western blotting}

Cell lysate for western blotting was prepared in $1 \times$ SDS-sample buffer, with the final concentration of $10^{4}$ cells $/ \mu \mathrm{L}$. $3 \mu \mathrm{L}$ lysates were resolved on a $10 \%$ SDS-PAGE gel, and proteins were transferred to a polyvinylidene difluoride membrane. The membrane was probed consecutively with primary and peroxidase-conjugated secondary antibodies, and the signal was detected using the SuperSignal West Pico Chemiluminescence Substrate system (Prod \#34077, Pierce). Primary and secondary antibodies used in this study were mouse anti-phospho-H2AX (Upstate), mouse anti-tubulin (Sigma), mouse anti-p21 (Santa Cruz), rabbit anti-p53 (Santa Cruz), chicken antiRAD9, anti-HUS1, peroxidase-conjugated anti-chicken IgY (A9046, Sigma), peroxidase-conjugated anti-mouse IgG (A9044, Sigma), and peroxidase-conjugated anti-rabbit IgG (A9169, Sigma). The antiRAD9 and anti-HUS1 antibodies were isolated from the eggs of chickens immunized with full-length human RAD9 and HUS1 proteins, respectively.

\section{Cell survival assays}

ES cells were plated in duplicate or triplicate and grown for $16 \mathrm{~h}$ before treatment. To test hydroxyurea $(\mathrm{HU})$ sensitivity, the drug was added to the medium to achieve the designated final concentrations. After $24 \mathrm{~h}$ incubation, cells were washed twice with phosphatebuffered saline (PBS), a fresh medium without HU was added back, and the cells were incubated for 10 more days before Giemsa stain and colony counting. To assess the ionizing radiation sensitivity, cells were exposed to graded doses of gamma rays using a ${ }^{60} \mathrm{Co}$-based 
irradiator, and incubated for another 10 days to allow colony formation. To determine the sensitivity to 254-nm UV light, the medium was removed, and the cells were exposed to graded doses of the UV light, and then the fresh medium was added to the cells, which were incubated for 10 more days before colony number was assessed. Survival percentage was calculated as $100 \times[$ (number of colonies in treated dishes/number of cells seeded in treated dishes)/(number of colonies in mock-treated control dishes/number of cells seeded in mock-treated control dishes)]. Mean values were derived from three independent replicates, and the standard deviations were calculated.

\section{Assays for cell cycle checkpoint functions}

To evaluate $\mathrm{G}_{2} / \mathrm{M}$ checkpoint control, $10^{6}$ cells were plated on $10-\mathrm{cm}$ dishes and incubated at $37^{\circ} \mathrm{C}$ in $5 \% \mathrm{CO}_{2}$ overnight. Two sets of cells were exposed to $10 \mathrm{~Gy}$ of gamma rays, with one set mock treated as a control. Immediately after irradiation, colcemid (final concentration of $50 \mathrm{ng} / \mathrm{mL}$ ) was added to one irradiated set of cells, which were subsequently incubated for various times at $37^{\circ} \mathrm{C}$. Cells were processed, stained with propidium iodide (PI) and analyzed by an FACSCalibur flow cytometer (Becton Dickinson) using an established method (Hang and Fox, 2004).

$\mathrm{S} / \mathrm{M}$ checkpoint function was examined using published procedures (Hu et al., 2008). Briefly, ES cells were grown to $70 \%$ confluence, and $1 \mathrm{mmol} / \mathrm{L} \mathrm{HU}$ was added to the medium to achieve a drug concentration of $1 \mathrm{mmol} / \mathrm{L}$. Cells were incubated at $37^{\circ} \mathrm{C}$ in $5 \%$ $\mathrm{CO}_{2}$ for various times, processed and suspended in PBS. The cells were probed with rabbit anti-phospho-histone H3 (Upstate), then FITC-conjugated anti-rabbit antibodies (Jackson ImmunoResearch Laboratories, INC), and stained with PI before flow cytometric analysis.

Intra-S phase checkpoint function was also evaluated by radioresistant DNA synthesis (RDS) assay in the BrdU labeling experiment (Hang and Fox, 2004). Briefly, cells were grown to $70 \%$ confluence. The medium was removed and cells were exposed to $20 \mathrm{~J} / \mathrm{m}^{2} \mathrm{UV}$ light. Afterwards, pre-warmed medium was added back to dishes, and cells were re-incubated at $37^{\circ} \mathrm{C}$. At various times after UV treatment, $10 \mu \mathrm{mol} / \mathrm{L} \mathrm{BrdU}$ was added to the medium and cells were pulselabeled for $10 \mathrm{~min}$. After processed, probed with FITC-conjugated anti-BrdU antibody, and stained with PI, cells were subjected to flow cytometric analysis.

\section{Comet assay}

An alkaline comet assay for detecting DNA damage was carried out with the CometAssay kit as described by the manufacturer (TREVIGEN). Briefly, comet assay slides were loaded with a mixture of $10 \mu \mathrm{L}$ of ES cell suspension $\left(5 \times 10^{5}\right.$ cells $\left./ \mathrm{mL}\right)$ and $90 \mu \mathrm{L}$ of lowtemperature melt agarose at a final concentration of $0.75 \%$. After solidification, slides were lysed at $4^{\circ} \mathrm{C}$ in darkness for $1 \mathrm{~h}$ in lysis solution. The slides were soaked and subjected to electrophoresis in alkaline solution, washed and stained with SYBR Green $(0.1 \mu \mathrm{g} / \mathrm{mL})$. The comet images were captured using a fluorescence microscope (Nikon). The tail moment was analyzed using Euclid comet analysis software (Euclid Analysis, St. Louis, MO).

\section{Immunofluorescence assay}

Cells grown on coverslips were fixed with $4 \%$ paraformaldehyde in PBS for $15 \mathrm{~min}$ at room temperature. The coverslips were washed in
PBS twice, incubated in PBS containing $0.5 \%$ Triton-X100 for $15 \mathrm{~min}$, then in PBS containing 5\% BSA and $0.1 \%$ Triton-X100 for $1 \mathrm{~h}$, washed in PBS again, and incubated with anti-phospho- $\mathrm{H} 2 \mathrm{AX}$ (Upstate) primary antibody (1:100 dilution) in PBS containing 5\% BSA and $0.1 \%$ Triton- $\mathrm{X} 100$ for $1 \mathrm{~h}$ at $37^{\circ} \mathrm{C}$. Afterwards, coverslips were washed twice for 5 min each in PBS and incubated with FITCconjugated anti-mouse antibody (1:100 dilution in PBS containing 5\% BSA and $0.1 \%$ Triton-X100) for $1 \mathrm{~h}$ at $37^{\circ} \mathrm{C}$. Finally, the coverslips were counterstained with DAPI $(10 \mathrm{ng} / \mathrm{mL})$. The images were captured using a fluorescence microscope (Nikon).

\section{Homology-directed recombination assay}

ES cell clone with the integrated homologous recombination reporter DR-GFP was generated as described previously (Pierce et al., 2001). $70 \mu \mathrm{g}$ of the hprtDRGFP plasmid digested with $\mathrm{Kpnl} / \mathrm{Sacl}$ was transfected into $2 \times 10^{7}$ cells in $0.8 \mathrm{~mL}$ of PBS using an electroporator at $800 \mathrm{~V}$ and $10 \mu \mathrm{F}$. Then cells were plated onto 5 plates, selected by puromycin $(1.2 \mu \mathrm{g} / \mathrm{mL})$ for 7 days and then by $2 \mu \mathrm{mol} / \mathrm{L}$ 6-thioguanine for another 7 days, and the remaining colonies were isolated. The IScel expression vector pCBASce was transfected using a Lipofectamine plus protocol. $10^{5}$ ES cells were plated onto a 6-well dish, and transfected with $1 \mu \mathrm{g} \mathrm{I-Scel} \mathrm{plasmid} \mathrm{using} \mathrm{the} \mathrm{Lipofectamine} \mathrm{plus}$ mixture on the next day. Cells were incubated for $48 \mathrm{~h}$, and then analyzed by FACSCalibur cytometer (Becton Dickinson).

\section{ACKNOWLEDGEMENTS}

This work was supported by the National Natural Science Foundation of China (Grant No. 30900813 to ZSH) and the Knowledge Innovation Program of Chinese Academy of Sciences to HH (Grant No. KSCX2YW-R63).

\section{ABBREVIATIONS}

BrdU, bromodeoxyuridine; ES, embryonic stem; DSBs, double-strand breaks; HR, homologous recombination; HU, hydroxyurea; LIF, leukemia inhibitory factor; MEF, mouse embryonic fibroblasts; NHEJ, non-homologous end joining; PI, propidium iodide; RA, retinoic acid; UV, ultraviolet

\section{REFERENCES}

al-Khodairy, F., and Carr, A.M. (1992). DNA repair mutants defining G2 checkpoint pathways in Schizosaccharomyces pombe. EMBO J 11, 1343-1350.

Aladjem, M.I., Spike, B.T., Rodewald, L.W., Hope, T.J., Klemm, M., Jaenisch, R., and Wahl, G.M. (1998). ES cells do not activate p53dependent stress responses and undergo p53-independent apoptosis in response to DNA damage. Curr Biol 8, 145-155.

An, L., Wang, Y., Liu, Y., Yang, X., Liu, C., Hu, Z., He, W., Song, W., and Hang, H. (2010). Rad9 is required for $B$ cell proliferation and immunoglobulin class switch recombination. J Biol Chem 285, 35267-35273.

Bao, S., Lu, T., Wang, X., Zheng, H., Wang, L.E., Wei, Q., Hittelman, W.N., and Li, L. (2004). Disruption of the Rad9/Rad1/Hus1 (9-1-1) complex leads to checkpoint signaling and replication defects. Oncogene 23, 5586-5593.

Bermudez, V.P., Lindsey-Boltz, L.A., Cesare, A.J., Maniwa, Y., 
Griffith, J.D., Hurwitz, J., and Sancar, A. (2003). Loading of the human 9-1-1 checkpoint complex onto DNA by the checkpoint clamp loader hRad17-replication factor $\mathrm{C}$ complex in vitro. Proc Natl Acad Sci U S A 100, 1633-1638.

Burtelow, M.A., Roos-Mattjus, P.M., Rauen, M., Babendure, J.R., and Karnitz, L.M. (2001). Reconstitution and molecular analysis of the hRad9-hHus1-hRad1 (9-1-1) DNA damage responsive checkpoint complex. J Biol Chem 276, 25903-25909.

Doré, A.S., Kilkenny, M.L., Rzechorzek, N.J., and Pearl, L.H. (2009). Crystal structure of the rad9-rad1-hus1 DNA damage checkpoint complex-implications for clamp loading and regulation. Mol Cell 34, 735-745.

Ellison, V., and Stillman, B. (2003). Biochemical characterization of DNA damage checkpoint complexes: clamp loader and clamp complexes with specificity for 5 ' recessed DNA. PLoS Biol 1, E33.

Enoch, T., Carr, A.M., and Nurse, P. (1992). Fission yeast genes involved in coupling mitosis to completion of DNA replication. Genes Dev 6, 2035-2046.

Freire, R., Murguía, J.R., Tarsounas, M., Lowndes, N.F., Moens, P.B., and Jackson, S.P. (1998). Human and mouse homologs of Schizosaccharomyces pombe rad1(+) and Saccharomyces cerevisiae RAD17: linkage to checkpoint control and mammalian meiosis. Genes Dev 12, 2560-2573.

Han, L., Hu, Z., Liu, Y., Wang, X., Hopkins, K.M., Lieberman, H.B., and Hang, H. (2010). Mouse Rad1 deletion enhances susceptibility for skin tumor development. Mol Cancer 9, 67.

Hang, H., and Fox, M.H. (2004). Analysis of the mammalian cell cycle by flow cytometry. Methods Mol Biol 241, 23-35.

Hang, H., and Lieberman, H.B. (2000). Physical interactions among human checkpoint control proteins HUS1p, RAD1p, and RAD9p, and implications for the regulation of cell cycle progression. Genomics 65, 24-33.

Hartwell, L.H., and Weinert, T.A. (1989). Checkpoints: controls that ensure the order of cell cycle events. Science 246, 629-634.

Hopkins, K.M., Auerbach, W., Wang, X.Y., Hande, M.P., Hang, H., Wolgemuth, D.J., Joyner, A.L., and Lieberman, H.B. (2004). Deletion of mouse rad9 causes abnormal cellular responses to DNA damage, genomic instability, and embryonic lethality. Mol Cell Biol 24, 7235-7248.

Hu, Z., Liu, Y., Zhang, C., Zhao, Y., He, W., Han, L., Yang, L., Hopkins, K.M., Yang, X., Lieberman, H.B., et al. (2008). Targeted deletion of Rad9 in mouse skin keratinocytes enhances genotoxin-induced tumor development. Cancer Res 68, 5552-5561.

Levitt, P.S., Liu, H., Manning, C., and Weiss, R.S. (2005). Conditional inactivation of the mouse Hus1 cell cycle checkpoint gene. Genomics 86, 212-224.

Levitt, P.S., Zhu, M., Cassano, A., Yazinski, S.A., Liu, H., Darfler, J., Peters, R.M., and Weiss, R.S. (2007). Genome maintenance defects in cultured cells and mice following partial inactivation of the essential cell cycle checkpoint gene Hus1. Mol Cell Biol 27, 2189-2201.

Lieberman, H.B., Hopkins, K.M., Laverty, M., and Chu, H.M. (1992). Molecular cloning and analysis of Schizosaccharomyces pombe rad9, a gene involved in DNA repair and mutagenesis. Mol Gen Genet 232, 367-376.

Lindsey-Boltz, L.A., Bermudez, V.P., Hurwitz, J., and Sancar, A. (2001). Purification and characterization of human DNA damage checkpoint Rad complexes. Proc Natl Acad Sci U S A 98,
$11236-11241$.

Longhese, M.P., Paciotti, V., Fraschini, R., Zaccarini, R., Plevani, P., and Lucchini, G. (1997). The novel DNA damage checkpoint protein ddc1p is phosphorylated periodically during the cell cycle and in response to DNA damage in budding yeast. EMBO $\mathrm{J} \mathrm{16,}$ 5216-5226.

Lydall, D., and Weinert, T. (1997). G2/M checkpoint genes of Saccharomyces cerevisiae: further evidence for roles in DNA replication and/or repair. Mol Gen Genet 256, 638-651.

Maynard, S., Swistowska, A.M., Lee, J.W., Liu, Y., Liu, S.T., Da Cruz, A.B., Rao, M., de Souza-Pinto, N.C., Zeng, X., and Bohr, V.A. (2008). Human embryonic stem cells have enhanced repair of multiple forms of DNA damage. Stem Cells 26, 2266-2274.

Murray, J.M., Carr, A.M., Lehmann, A.R., and Watts, F.Z. (1991). Cloning and characterisation of the rad9 DNA repair gene from Schizosaccharomyces pombe. Nucleic Acids Res 19, 3525-3531.

Parker, A.E., Van de Weyer, I., Laus, M.C., Oostveen, I., Yon, J., Verhasselt, P., and Luyten, W.H. (1998). A human homologue of the Schizosaccharomyces pombe rad1+ checkpoint gene encodes an exonuclease. J Biol Chem 273, 18332-18339.

Parrilla-Castellar, E.R., Arlander, S.J., and Karnitz, L. (2004). Dial 91-1 for DNA damage: the Rad9-Hus1-Rad1 (9-1-1) clamp complex. DNA Repair (Amst) 3, 1009-1014.

Paulovich, A.G., and Hartwell, L.H. (1995). A checkpoint regulates the rate of progression through $S$ phase in $S$. cerevisiae in response to DNA damage. Cell 82, 841-847.

Pierce, A.J., Hu, P., Han, M., Ellis, N., and Jasin, M. (2001). Ku DNA end-binding protein modulates homologous repair of double-strand breaks in mammalian cells. Genes Dev 15, 3237-3242.

Rauen, M., Burtelow, M.A., Dufault, V.M., and Karnitz, L.M. (2000). The human checkpoint protein hRad17 interacts with the PCNAlike proteins hRad1, hHus1, and hRad9. J Biol Chem 275, 29767-29771.

Roos-Mattjus, P., Vroman, B.T., Burtelow, M.A., Rauen, M., Eapen, A. K., and Karnitz, L.M. (2002). Genotoxin-induced Rad9-Hus1-Rad1 (9-1-1) chromatin association is an early checkpoint signaling event. J Biol Chem 277, 43809-43812.

Rowley, R., Subramani, S., and Young, P.G. (1992). Checkpoint controls in Schizosaccharomyces pombe: rad1. EMBO J 11, 1335-1342.

Shiomi, Y., Shinozaki, A., Nakada, D., Sugimoto, K., Usukura, J., Obuse, C., and Tsurimoto, T. (2002). Clamp and clamp loader structures of the human checkpoint protein complexes, Rad9-1-1 and Rad17-RFC. Genes Cells 7, 861-868.

Sohn, S.Y., and Cho, Y. (2009). Crystal structure of the human rad9hus1-rad1 clamp. J Mol Biol 390, 490-502.

Tichy, E.D., and Stambrook, P.J. (2008). DNA repair in murine embryonic stem cells and differentiated cells. Exp Cell Res 314, $1929-1936$.

Udell, C.M., Lee, S.K., and Davey, S. (1998). HRAD1 and MRAD1 encode mammalian homologues of the fission yeast rad1(+) cell cycle checkpoint control gene. Nucleic Acids Res 26, 3971-3976.

Wang, X., Guan, J., Hu, B., Weiss, R.S., Iliakis, G., and Wang, Y. (2004). Involvement of Hus1 in the chain elongation step of DNA replication after exposure to camptothecin or ionizing radiation. Nucleic Acids Res 32, 767-775.

Wang, X., Hu, B., Weiss, R.S., and Wang, Y. (2006). The effect of Hus1 on ionizing radiation sensitivity is associated with homologous recombination repair but is independent of nonhomologous 
end-joining. Oncogene 25, 1980-1983.

Weiss, R.S., Enoch, T., and Leder, P. (2000). Inactivation of mouse Hus1 results in genomic instability and impaired responses to genotoxic stress. Genes Dev 14, 1886-1898.

Weiss, R.S., Leder, P., and Vaziri, C. (2003). Critical role for mouse Hus1 in an S-phase DNA damage cell cycle checkpoint. Mol Cell Biol 23, 791-803.

Xu, M., Bai, L., Gong, Y., Xie, W., Hang, H., and Jiang, T. (2009). Structure and functional implications of the human rad9-hus1-rad1 cell cycle checkpoint complex. J Biol Chem 284, 20457-20461.

Yazinski, S.A., Westcott, P.M., Ong, K., Pinkas, J., Peters, R.M., and Weiss, R.S. (2009). Dual inactivation of Hus1 and p53 in the mouse mammary gland results in accumulation of damaged cells and impaired tissue regeneration. Proc Natl Acad Sci U S A 106, 21282-21287.

Zhou, M., Zheng, L., Guo, L., and Ding, Z. (2010). Cell Biological Effect and Mechanism of Ultraviolet Radiation. Acta Biophysica Sinica 26, 950-958. 